\title{
Performance of Cajanus cajan [I.] millsp. and Sesbania sesban as cooking fuel
}

\author{
Adelanwa, E. B. ${ }^{*}$ and Tijani, M. O. \\ Department of biological sciences, Ahmadu Bello University, Zairi, Nigeria. \\ *Corresponding Author. Email: estherlanwa@yahoo.com, estherlanwa@gmail.com. Tel: 08036185814, 08054536120.
}

Copyright ( 2016 Adelanwa and Tijani . This article remains permanently open access under the terms of the Creative Commons Attribution License 4.0, which permits unrestricted use, distribution, and reproduction in any medium, provided the original work is properly cited.

Received 1st February, 2016; Accepted 12th March, 2016

\begin{abstract}
Studies on the performance of Cajanus cajan and Sesbania sesban as cooking fuel was carried out. The germination rate was monitored from outset of the cotyledon till maturity within six months and the biomass was compared with Isoberlinia doka. Seedlings were established in the field in the fourth week on a single row per ridge with an interval of $30 \mathrm{~cm}$. The growth rate was monitored in the field and the length of the stem, length and width of the leaf was taken. The stalks of Cajanus cajan became wood, the biomass was checked with Isoberlinia doka which is a major fire wood used by the people in Samaru, Zaria. It was observed that Cajanus cajan boiled $5000 \mathrm{ml}$ of water within 20 minutes, 16 seconds while it took Isoberlinia doka 17 minutes, 20 seconds to boil the same volume of water.
\end{abstract}

KEYWORDS: Cajanus cajan, Sesbania sesban, Isoberlina doka, biomass.

\section{INTRODUCTION}

The demand for trees as fuel wood in Nigeria have grown rapidly which has led to cutting down and clearing away forest on a very large scale. This action usually has significant impact on weather conditions. Cajanus cajan has been selected as one of the most promising food crops for the semi-arid tropics. It gives economic yield of seeds in areas where rainfall is about $400 \mathrm{~mm}$ annually (Nene and Sheila, 1990). Pigeon pea [Cajanus cajan (L.) Millsp.] is a valuable multipurpose drought tolerant crop (Mergeai et al., 2001) that is grown for food and fuel wood in the tropical and sub-tropical areas of India, Africa, south East Asia and Central America. Cajanus cajan is ranked sixth in the world, in production of dry land legumes (Nene and sheila, 1990).

Cajanus cajan (L.) Millsp. is a leguminous fast growing perennial woody crop with tall woody stalk which has been considered as a producer of fuel wood and can be used as cooking fuel. Nevertheless, they are crops that can produce both food and fuel wood within 3-6 months. They can be used as a rotation crop to grow fuel wood as well as fertilize the soil in preparation for food crops (Raju et al., 2010). It is among the best nitrogen-fixing legumes and is mostly woody shrub that can grow as tall as $3.6-4.0 \mathrm{~m}$. It was found that, the spindly stalks are extensively used as fuel wood for cooking in Indian villages. In the past their stalks were employed for making charcoal used in the production of gun powder (Arihana et al., 2003). Their pods, husks and foliage can be used for feeding animals. The plant has also been cultivated for feeding silkworms and the lac insects from which shellac is obtained.

Cajanus cajan (L.) Millsp. is best sown in rows for inter row cultivation and mechanical harvesting. It can be seeded in holes about $2 \mathrm{~m}$ apart or in $35 \mathrm{~cm}$ rows for fine stems, for silage and mechanical harvesting. It is a heattolerant plant and prefers hot moist conditions. Under Hawaiian conditions, it grows between 18 and $30^{\circ} \mathrm{C}$. It will grow at temperatures above $35^{\circ} \mathrm{C}$ under adequate soil condition of moisture and fertility. Cajanus cajan does not tolerate frost level and it will seed as a perennial at $1840 \mathrm{~m}$ down to a minimum night temperature of $10^{\circ} \mathrm{C}$ (Krauss, 1936). The heat value of pigeon pea wood is estimated as one half of the same weight of coal, thus it serves as an alternative cooking fuel. The straight branches are use as light construction materials for roofing, fencing and baskets, hut construction and binding materials (Singh et al., 1990). Pigeon pea (Cajanus cajan) is one of the most common legumes of the tropics and sub-tropics with a wide adaptability (Wallis et al., 1988). Rachie (1975) 
reported that pigeon pea is a legume that shows great potential in Nigeria and to which effort of International Institute of Tropical Agriculture (IITA) were directed for improvement. The objectives of this research are to study the germination of Cajanus cajan and Sesbania sesban from outset of the cotyledon till maturity and to check whether the stalk of Cajanus cajan and Sesbania sesban can become wood within six months.

\section{MATERIALS AND METHODS}

This research was carried out in laboratory and botanical garden, Department of Biological sciences, Ahmadu Bello University, Zaria, located in northern guinea savannah zone of Nigeria and coordinates $\left(11^{0} 3 \mathrm{~N} ; 7^{0} 42 \mathrm{E}\right)$.

Seeds of Cajanus cajan, petri dishes, filter papers, beaker, polythene bags, sandy loam soil, pot, three big stones, spring balance and tape rule were used for the experiments. Seeds of Cajanus cajan were gotten from National Animal Production Research Institute (NAPRI) and Isoberlinia doka stalks were gotten from firewood seller in Samaru, Zaria.

Ten seeds of Cajanus cajan were placed inside twenty Petri dishes containing wet filter papers for three days. A seedling was transfered from the petri dishes to each polythene bag containing sandy loam soil. Polythene bags containing the seedlings were watered twice daily and germination was monitored to check the need for resowing. Four weeks after germination, seedling were established in the field on a single-row per ridge with an interval of $30 \mathrm{~cm}$ and watered twice daily. The growth rate was monitored in the field. After the Cajanus cajan has matured into wood, the biomass was then compared with Isoberlinia doka.

The stalks of Cajanus cajan were first cut from the field and sun dried for three weeks, and it was finally oven dried for five hours. The weight of Cajanus cajan and Isoberlinia doka stalks were taken by the use of spring balance. Then three stones were arranged and the Cajanus cajan dried stalks was arranged in the middle of the three stone. The Cajanus cajan stalks were then set into fire and they were allowed to burn. Then a pot containing $1000 \mathrm{ml}$ of water was placed on the fire. The experiments was repeated with $2000 \mathrm{ml}, 3000 \mathrm{ml}, 4000 \mathrm{ml}$ and $5000 \mathrm{ml}$ of water, and the time taken for the water to boil was recorded using stop watch. The biomass of Isoberlinia doka was checked using the same procedure as was used in Cajanus cajan.

\section{RESULTS}

After two days of planting, it was observed that the seeds of Cajanus cajan in the petri dishes have germinated into radicle and plumule. Four days after the transplanting of the germinated Cajanus cajan seeds inside polythene bags, it was observed that the first foliage formed is bifoliate. After five days of emergence of the first foliage
Table 1. The parameter readings taking during the studying of growth rate of Cajanus cajan at four weeks after transplanting to the field.

\begin{tabular}{cccc}
\hline S/N & $\begin{array}{c}\text { Stem length } \\
(\mathbf{c m})\end{array}$ & $\begin{array}{c}\text { Leaf length } \\
(\mathbf{c m})\end{array}$ & $\begin{array}{c}\text { Leaf width } \\
(\mathbf{c m})\end{array}$ \\
\hline 1 & 19.30 & 5.30 & 1.20 \\
2 & 37.00 & 10.20 & 2.50 \\
3 & 30.20 & 7.50 & 1.80 \\
4 & 16.40 & 5.00 & 1.20 \\
5 & 25.30 & 8.60 & 2.20 \\
6 & 19.50 & 7.00 & 1.80 \\
7 & 33.00 & 8.70 & 2.20 \\
8 & 17.50 & 5.70 & 1.40 \\
9 & 29.00 & 8.20 & 2.20 \\
10 & 29.90 & 9.60 & 1.80 \\
11 & 22.10 & 6.60 & 1.20 \\
12 & 15.00 & 5.60 & 1.60 \\
13 & 14.90 & 4.30 & 1.70 \\
14 & 22.00 & 6.90 & 1.20 \\
15 & 24.50 & 7.70 & 2.10 \\
\hline
\end{tabular}

which was bifoliate, the second foliage was observed which was trifoliate. It was also observed that the first foliage which was bifoliate matured and drops to the ground while the formation of trifoliate continues throughout the growth of the plant.

\section{DISCUSSION}

The seeds of Cajanus cajan germinated and produced flower after 22 weeks; the stalks also became wood. The parameter readings of Table 1 show the length of stem in centimeter, the length of the leaf and it width increased as the days progressed and treatment such as water supplied continued. Table 1, 2, 3 and 4, showed that as the length of the stem of Cajanus cajan increased, the length of the leaf and width also incresed. This is in agreement with the work of Irmak et al., (2003) where it was documented that the growth of the stem, leaf and branch of Viburnum odoratissimum increased as the irrigation water applied increase. As it was represented in table 1 after four weeks of transplanting to the field, the lowest length of stem is $14.90 \mathrm{~cm}$ which increased to $87.90 \mathrm{~cm}$ after eight weeks as shown in table 2. The length and width of the leaf increased from $4.30 \mathrm{~cm}$ and $1.7 \mathrm{~cm}$ at weeks four to 6.70 $\mathrm{cm}$ and $3.10 \mathrm{~cm}$ respectively after eight weeks of transplanting as contained in table 2 while the largest length of the stem after four weeks is 37.00 and increase to $110.00 \mathrm{~cm}$ at the eight weeks (Tables 1 and 2). The length of the leaf as shown in table 1 increased from 10.2 $\mathrm{cm}$ to $12.60 \mathrm{~cm}$ while that of width increased from from $2.50 \mathrm{~cm}$ to $4.40 \mathrm{~cm}$ in accordance with number of weeks. This increment continued as contained in table 3 and 4 as 
Table 2. The parameter readings taking during the studying of the growth rate of Cajanus cajan at eight weeks.

\begin{tabular}{cccc}
\hline S/N & $\begin{array}{c}\text { Stem length } \\
\text { (cm) }\end{array}$ & $\begin{array}{c}\text { Leaf length } \\
\text { (cm) }\end{array}$ & $\begin{array}{c}\text { Leaf width } \\
\text { (cm) }\end{array}$ \\
\hline 1 & 92.30 & 7.70 & 3.10 \\
2 & 110.00 & 12.60 & 4.40 \\
3 & 103.20 & 9.90 & 3.70 \\
4 & 89.40 & 7.40 & 3.10 \\
5 & 98.30 & 11.00 & 4.10 \\
6 & 92.50 & 9.40 & 3.70 \\
7 & 106.00 & 11.10 & 4.10 \\
8 & 90.50 & 8.10 & 3.30 \\
9 & 102.00 & 10.60 & 4.10 \\
10 & 102.90 & 12.00 & 4.40 \\
11 & 95.10 & 9.00 & 3.90 \\
12 & 88.00 & 8.00 & 3.90 \\
13 & 87.90 & 6.70 & 3.10 \\
14 & 95.00 & 9.30 & 3.50 \\
15 & 97.50 & 10.10 & 3.60 \\
\hline
\end{tabular}

Table 3. The parameter readings taking during the studying of the growth rate of Cajanus cajan at twelve weeks.

\begin{tabular}{cccc}
\hline $\mathbf{S} / \mathbf{N}$ & $\begin{array}{c}\text { Stem length } \\
(\mathbf{c m})\end{array}$ & $\begin{array}{c}\text { Leaf length } \\
\text { (cm) }\end{array}$ & $\begin{array}{c}\text { Leaf width } \\
\text { (cm) }\end{array}$ \\
\hline 1 & 174 & 13.0 & 6.0 \\
2 & 206 & 13.0 & 5.0 \\
3 & 193 & 15.0 & 5.2 \\
4 & 170 & 14.0 & 5.3 \\
5 & 185 & 13.0 & 4.9 \\
6 & 179 & 14.7 & 5.3 \\
7 & 200 & 13.0 & 5.0 \\
8 & 171 & 13.5 & 5.2 \\
9 & 186 & 12.0 & 5.1 \\
10 & 189 & 15.0 & 5.0 \\
11 & 183 & 15.0 & 6.0 \\
12 & 168 & 12.0 & 5.0 \\
13 & 168 & 13.5 & 5.5 \\
14 & 182 & 13 & 5.1 \\
15 & 184 & 14 & 5.9 \\
\hline
\end{tabular}

the number of days and water applied increase.

Table 5 explained the time taken for Cajanus cajan to boil water. As the volume of the water increased from $1000 \mathrm{ml}$ to $2000 \mathrm{ml}, 3000 \mathrm{ml}, 4000 \mathrm{ml}$, and $5000 \mathrm{ml}$, the time it took to boil also increased from five minute twenty seconds, eight minute thirty seconds, twelve minute forty eight seconds, sixteen minute fifty five seconds and twenty minute sixteen seconds. Rao et al., (2003) documented the usefulness of Cajanus cajan that the sticks are important household fuel in many areas. They also
Table 4. The parameter readings taking during the studying of the growth rate of Cajanus cajan at sixteen weeks.

\begin{tabular}{cccc}
\hline S/N & $\begin{array}{c}\text { Stem length } \\
\text { (cm) }\end{array}$ & $\begin{array}{c}\text { Leaf length } \\
\text { (cm) }\end{array}$ & $\begin{array}{c}\text { Leaf width } \\
\text { (cm) }\end{array}$ \\
\hline 1 & 255.7 & 14.3 & 6.5 \\
2 & 287.0 & 14.2 & 5.2 \\
3 & 277.0 & 16.5 & 5.9 \\
4 & 250.5 & 14.9 & 5.9 \\
5 & 270.0 & 14.2 & 5.6 \\
6 & 260.7 & 15.2 & 5.3 \\
7 & 281.9 & 14.2 & 5.6 \\
8 & 252.3 & 14.0 & 5.8 \\
9 & 271.7 & 13.4 & 5.9 \\
10 & 270.6 & 16.7 & 5.7 \\
11 & 265.3 & 16.6 & 6.4 \\
12 & 251.7 & 13.7 & 5.7 \\
13 & 251.7 & 14.2 & 5.9 \\
14 & 268.0 & 14.0 & 5.6 \\
15 & 270.0 & 15.1 & 6.3 \\
\hline
\end{tabular}

Table 5. Time taken for Cajanus cajan to boil water when used as fuel wood.

\begin{tabular}{ccc}
\hline $\mathbf{S} / \mathbf{N}$ & Volume $(\mathbf{m l})$ & Time $(\mathbf{s e c})$ \\
\hline 1 & 1000 & 5.20 \\
2 & 2000 & 8.30 \\
3 & 3000 & 12.48 \\
4 & 4000 & 16.55 \\
5 & 5000 & 20.16 \\
\hline
\end{tabular}

Table 6. Time taken for Isoberlinia doka to boil water when used as fuel wood.

\begin{tabular}{ccc}
\hline $\mathbf{S} / \mathbf{N}$ & Volume $(\mathbf{m l})$ & Time $(\mathbf{s e c})$ \\
\hline 1 & 1000 & 3.18 \\
2 & 2000 & 6.30 \\
3 & 3000 & 10.16 \\
4 & 4000 & 14.50 \\
5 & 5000 & 17.20 \\
\hline
\end{tabular}

explained that the heat value is about half $(1 / 2)$ that of the same weight of coal, and it has several advantages over traditional trees, such as its rapid growth potential. Rao et al. (2003) also reported that farmers sow it not for the grain purposes but because of its wood. Its productivity levels make up for the comparatively poor fuel characteristics.

Table 6 explains the time taken for Isoberlinia doka to boil water. As the volume of the water increased from $1000 \mathrm{ml}, 2000,3000,4000$ and $5000 \mathrm{ml}$, the time it took to 
boil also increased from three minute eighteen seconds, six minute thirty seconds, ten minute sixteen seconds, fourteen minute fifty seconds and seventeen minute twenty seconds. This shows that it takes more time for Cajanus cajan to boil the same volume of water compare to Isoberlinia doka. Despite the short difference in time taken which is three minute ninety six seconds between Cajanus cajan and Isobrelinia doka to boil the same volume of water, Cajanus cajan can still be used as fuel wood in order to reduce deforestation on the forest which may lead to desertification. This is because the amount of Cajanus cajan used to boil $5000 \mathrm{ml}$ of water is small (less in weight ) compared to the amount of Isoberlinia doka used to boil the same volume of water. It was observed that the weight of Cajanus cajan used was $500 \mathrm{~g}$ to boil $5000 \mathrm{ml}$ of water for twenty minute sixteen seconds whereas Isoberlinia doka takes seventeen minute twenty seconds to boil the same volume of water using $1000 \mathrm{~g}$ of the wood stalk. This shows that Cajanus cajan burnt slowly and produce more heat while Isoberlinia doka burnt faster with more heat.

The research findings showed that Cajanus cajan can be used as cooking fuel. It has traditionally been a valuable crop. The woody stem serves as fuel and raw material for making huts, brooms and baskets. Tall perennial pigeonpea are often used as live fences, windbreaks and soil conservation in Africa (Phatak et al., 1993). Ease of establishment and the simultaneous production of food make perennial pigeon peas a special agro-foresrty option in several parts of Africa (Kwesiga et al., 2003). Akhtaruzzaman et al. (1986) reported that little was known about the efficient utilizationof the entire plant (pigeonpea) as a biofuel. This present study has proved that the entire plant can be used as fuel. Cajanus cajan can therefore be regarded as a potential source of bioenergy because of its high biomass yield in comparison to the amount of off-farm imputs used. This is in line with the work of Odeny (2007) where he reported that the use of perennial pigeonpea types are favoured for use as fuelwood, basket weaving and roofing in African villages. This is also in agreement with results obtained by several authors (Azam et al., 2005; De and Bhattacharyya, 1999; Karmee and Chadha, 2005) where it was recognized that Pongamia pinnata has potential as a source of fuel for the biodiesel industry.

\section{CONFLICT OF INTEREST}

The authors declare that they have no conflict of interest.

\section{Conclusion}

The results of this study showed that Cajanus cajan germinates, produce flowers and the stalks became wood. It also showed that the time taking for Isoberlinia doka to boil water is shorter compared to the time taken by
Cajanus cajan to boil water.

\section{REFERENCES}

Akhtaruzzaman, A. F. M., Siddique, A. B. \& Chowdhury, A. R. (1986). Potentiality of pigeonpea (arhar) plant for pulping. Bano Biggyan Patrika, 15(1-2), 31-36.

Arihana, A.N., Okada, J., Yoshihara, K., \& Johansen, C. (2003). Phosphorus uptake by pigeon pea and its role in cropping systems of the Indian subcontinent. Science, 248, 47-480.

Azam, M. M., Waris, A. \& Nahar, N. M. (2005). Prospects and potential of fatty acid methyl esters of some non-traditional seed oils for use as biodiesel in India. Biomass and Bioenergy, 29, 293-302.

De, B. K. \& Bhattacharyya, D. K. (1999). Biodiesel from minor vegetable oils like karanja oil and nahar oil. Lipid Felt, 101, 404-406.

Irmak, S., Haman, D.Z., Irmak, A., Jones, J. W., Campbell, K.L., \& Yeager, T. H. (2003). New irrigation - plant production system for water conservation in ornamental nurseries: Quantification and evaluation of irrigation runoff, plant biomass, and irrigation efficiencies. Applied Engineering in Agriculture, ASAE 19(6), 651-665.

Karmee, S. J., \& Chadha, A. (2005). Preparation of biodiesel from crude oil of Pongamia pinnata. Bioresource Technology, 96, 1425-1429.

Krauss, F.G. (1936). Pigeon peas as human food and as a feed for livestock. Univ. Hawaii Coop. Ext.Service. Agricultural Notes AN-125, 4p.

Kwesiga, F., Akinnifesi, F. K., Mafongoya, P. L., McDermot, M. H. \& Agumya, A. (2003). Agroforestry research and development in southern Africa during the 1990s. Review and challenges ahead. Agroforestry Systems, 59, 173-186.

Mergeai, G., Kimani, P., Mwangombe, A., Olubayo, F., Smith, C., Audi,P., Baudoin, J. P., \& Le Roi, A. (2001). Survey of pigeonpea productionsystems, utilization and marketing in semi-arid lands of Kenya. Biotechnology, Agronomy, Society and Environment, 5(3), 145-153.

Nene, Y.L., \& Sheila, V.K. (1990) Pigeon pea: Geography and importance. In: Nene, Y.L., Hall, S. D. and Sheila, V. K. (Eds.). The Pigeonpea, Wallingford, Oxon, UK: CAB International, 114.

Odeny, D. A. (2007). The potential of pigeonpea (Cajanus cajan) (L) Millsp.) in Africa. Natural Resources Forum, 31, 297-305.

Phatak, S. C., Nadimpalli, R. G.,Tiwari, S. C. \& Bhardwaj, H. L. (1993). Pigeonpeas: Potential new crop for the Southeastern United states. In: Jamick, J. \& Simon, J. E. (Eds), New Crops. Wiley, New York, Pp.597-599.

Rachie, K. O. (1975). The nutritional role of grain legumes in lowland humid Tropics. In: Biological fixation in farming systems of the Tropics. Ayabana, A. andDart, P. J. (Eds). Based on papers presented at a symposium held at IITA, Ibadan, Nigeria, Pp.272-275.

Raju, N. L., Gnanesh, B. N., Lekha, P. (2010). The first set of EST resource for gene discovery and marker development in pigeonpea (Cajanus cajan L.). BMC Plant Biology, 10, 45.

Rao, S.C., Phillips, W.A., Mayeux, H.S., \& Phatak, S. C. (2003). Potential grain and forage production of early maturing pigeon pea in the southern Great Plains. Crop Science, 43, 2212 2217.

Singh, U., Jambunathan, R., Saxena, K. B., \& Subrah-manyam, N. (1990). Nutritional quality evaluation of newly developed high-protein genotypes of pigeonpea (Cajanus cajan L.). 
Journal of the Science of Food and Agriculture, 50, 201-209. Wallis, E. S., Faris, D. G., Elliot, R., \& Byth, D. E., (1988). Varietalimprovement of pigeonpea for small-holder livestock production systems. Proceedings of workshop on CropLivestock Systems Research, July 7-11 1986, Khon Kaen, Thailand. 